\title{
Recovery of Indium from Mobile Phone Touch Screen Using Adapted Acidithiobacillus ferrooxidans
}

\author{
Omid Rezaei, Seyyed Mohammad Mousavi*, Fatemeh Pourhossein \\ Biotechnology Group, Chemical Engineering Department, Tarbiat Modares University, Tehran, Iran. \\ * Corresponding author. Tel.: +98-21-82884917; fax: +98-21-82884931; email: mousavi_m@modares.ac.ir \\ Manuscript submitted May 15, 2017; accepted December 15, 2017.
}

doi: 10.17706/ijbbb.2018.8.2.117-124

\begin{abstract}
The toxicity of heavy metals has important role in thermophilic microorganism growth in bioleaching of e-waste. The mobile phone touch screen has high concentration of several heavy metals that caused negative effect on bacterial activity and metals recovery. In the present investigation, Acidithiobacillus ferrooxidans was adapted to powder of mobile phone touch screen. The serial subculturing approach was used for bacterial adaptation with heavy metals. The experiments began with $0.1 \mathrm{wt} / \mathrm{vol} . \%$ pulp density eventually increase to $2.5 \mathrm{wt} / \mathrm{vol} . \%$. All experiment conducted in $100 \mathrm{ml} 9 \mathrm{k}$ medium at the initial $\mathrm{pH} 2$ and $2 \%(\mathrm{v} / \mathrm{v})$ inoculums. The effective parameters such as $\mathrm{pH}, \mathrm{Eh}, \mathrm{Fe}^{3+}$, cell concentration were studied and the results confirmed as well as each other. Indium recovery for adapted cell, non-adapted cell and control were $100 \%$ (adapted), $10 \%$ (non-adapted), $1 \%$ (control), respectively. Finally, it is essential that the bacteria become adapted with the heavy metals and consequently an acceptable bioleaching process will be achieved.
\end{abstract}

Key words: Bioleaching, adaptation, e-waste, Acidithiobacillus ferrooxidans.

\section{Introduction}

In recent years, the amount of solid electro nic waste generation increased and it is a big problem for society, governments and the technology industry, therefore the developing countries will face a great challenge [1]. Among the e-waste the mobile phones waste generation is growing quickly because of the lifetime of these electronic devices is generally 1-3 years [2]. The mobile phone is composed of different parts such as battery, display and electronic boards and according to research approximately $80 \%$ of materials in mobile phone is recyclable [3]. Screens are one of the most important parts of mobile phones that contains glass, organic materials and indium which is present in a layer is called indium-tin oxide (ITO). The important point is $70 \%$ of indium consumption related to ITO production [4]. Indium is a rare metals and present in small amount $(0.24) \mathrm{ppm}$ in the crust of earth and it is obtained as by-product of zinc mining about 1-100ppm [5] The amount of indium in mobile phone screens can be up to $250 \mathrm{ppm}$. In finally recovery of indium from mobile phone waste is necessary for return to the consumption cycle.

In recent decade, the recovery of metals from e-wastes is performed using biotechnology process. Bioleaching means to employ the microorganisms to solubilize and recover metal from solid waste [6]. There are many advantages for bioleaching process in comparison to conventional methods such as lower cost, minimization of use of chemical materials [7], low energy requirement, decrease the requirement for natural resources and the landfill spaces [6] as well as there is little disadvantages for this method such as 
longer leaching time and the restrictions for the bacteria [8]. One of these limitations is high toxic of heavy metal concentrations [6]. The mobile phone touch screen has high concentration of heavy metals such as Sr, $\mathrm{Ni}, \mathrm{Cr}$. The bacterial activity decreases when the microorganism exposure with mobile phone touch screen due to three reason: 1) decreasing in oxygen and carbon dioxide transmission rate, 2) mechanical injury to the bacterial cells as a result erosion between the cells and particles of waste, 3) the toxic effects of metal ions on bacterial cells [9].The adaptation of $A$. ferrooxidans cells to heavy metal ion performed by serial sub-culturing method and according to this the metal concentration in the medium increased gradually [9]. The adaptation criterion plays crucial role in adaptation process [10] Xia et al (2008) reported that adaptation criterion is based on cell concentration and when cell concentration reached to $10^{7} \mathrm{cells} / \mathrm{ml}$ can be adapted bacteria [11]. Astudillo and Acevedo showed the adaptation criterion was notable appearance the amount of dissolved copper, iron and a $\mathrm{Fe}^{+2} / \mathrm{Fe}^{+3}$ ratio under one. in this research adaptation criterion is considered cell concentration and Its value is $5 \times 10^{7}$ cells $/ \mathrm{ml}$ [12].

Mobile phone contains a variety of valuable materials, such as metals, glass, plastics so process for adaptation of the bacteria will be more complex [3]. In this study main purpose was investigation of various parameters such as $\mathrm{pH}, \mathrm{Eh}, \mathrm{Fe}^{3+}$, cell concentration during the adaptation and impact of adaptation on the metal recovery.

\section{Materials and Methods}

\subsection{Microorganism and Bacterial Culture}

The native strain of Acidithiobacillus ferrooxidans (PTCC 1647) was provided from the Iranian Research Organization for Science and Technology (IROST) in Tehran. The 9K medium contained $3 \mathrm{~g}\left(\mathrm{NH}_{4}\right)_{2} \mathrm{SO}_{4}, 0.5 \mathrm{~g}$ $\mathrm{K}_{2} \mathrm{HPO}_{4}, 0.5 \mathrm{~g} \mathrm{MgSO}_{4} .7 \mathrm{H}_{2} \mathrm{O}, 0.1 \mathrm{~g} \mathrm{KCl}, 0.01 \mathrm{~g} \mathrm{Ca}\left(\mathrm{NO}_{3}\right)_{2}$ and $44.22 \mathrm{~g} \mathrm{FeSO}_{4}$ as an energy source for growth of $A$. ferrooxidans solved in $1 \mathrm{~L}$ distilled water.

\subsection{Adaptation Technique and Analysis}

Adaptation was performed in 250 m erlenmeyer flask with 9K medium in an incubator at $140 \mathrm{rpm}$ and $30{ }^{\circ} \mathrm{C}$. The flasks were inoculated with $2 \% \mathrm{v} / \mathrm{v}$ of active culture and Initial $\mathrm{pH}$ was adjusted to 2 with sulfuric acid. The adaptation process was done by serial subculturing method, the concentration of mobile phone screen powder increased from 1 to $25 \mathrm{~g} / \mathrm{L}$ (pulp density $0.1 \%-2.5 \%$ ) in this method when the number of bacteria cell was bigger than $5 \times 10^{7}$ cells $/ \mathrm{ml}$ the bacteria adapted and can transfer to higher pulp density Inductively coupled plasma optical emission spectrometry (ICP-OES) was used to detect metal concentration in mobile phone screen powder and represented in Table 1.

Table 1. Chemical Composition of the Mobile Phone Touch Screen Using ICP

\begin{tabular}{cc}
\hline \hline Element & Concentration $(\mathrm{mg} / \mathrm{kg})$ \\
\hline $\mathrm{Al}$ & 93561 \\
$\mathrm{Sr}$ & 20575 \\
$\mathrm{In}$ & 69 \\
$\mathrm{Mn}$ & 340 \\
\hline \hline
\end{tabular}

\subsection{Analytical Methods}

The ferric ion concentration in solution measured by5-Sulfosalicylic acid (SSA) testing method. In this method $0.1 \mathrm{~mL}$ of the culture solution was mixed with $3 \mathrm{~mL}$ of $10 \% 5$-sulfo-salicylic acid (SSA) followed in $100 \mathrm{~mL}$ of distilled water in finally the light absorbance was measured at $500 \mathrm{~nm}$ using UV-VIS (Optizen 3220UV, Korea) [13]. Eh meter (model: Metrohm, 691) was used to monitor the Eh change during adaptation process also the acidity of the solution was measured by pH meter (model: CP-500L, IsTek). The 
bacteria cell number counted by a hemocytometer under a phase-contrast microscope (Zeiss, Germany). The flasks shaked inside the incubators (Wise Cube, South Korea). Metal ion concentration was analyzed by ICP-OES (Vistapro, Australia). The Phenom XL Scanning Electron Microscope (SEM) was applied for investigation of surface morphology of the powder before and after bioleaching.

\section{Results and Discussion}

\subsection{Variation of $\mathbf{p H}$}

The change of $\mathrm{pH}$ in a variety of pulp density is shown in Fig. 1. Initially, the $\mathrm{pH}$ increases because of two reasons, the first reason is acidconsuming by A. ferrooxidans. The bacteria for growth consumed oxygen and protons and oxidized ferrous ions Eq. (1):

$$
\mathrm{Fe}^{2+}+0.25 \mathrm{O}_{2}+\mathrm{H}^{+} \text {A.ferrooxidans } \mathrm{Fe}^{3+}+0.5 \mathrm{H}_{2} \mathrm{O}
$$

The second reason related to powder structure that is neutral. This claim is based on the $\mathrm{pH}$ determination analysis according to this analysis a $1 \mathrm{gr}$ of powder of sample was dissolved in $50 \mathrm{ml}$ of distilled water [14] and placed in a shaker incubator was observed $\mathrm{pH}$ of solution was fixed in the range of 7. this analysis proved powder neutrality. Finally the $\mathrm{pH}$ increases until the third day and then $\mathrm{pH}$ decreases because of the ferric ion hydrolysis and protons released (Eq.2-4) [15].

$$
\begin{gathered}
\mathrm{Fe}^{3+}+\mathrm{H}_{2} \mathrm{O} \leftrightarrow \mathrm{Fe}(\mathrm{OH})^{2+}+\mathrm{H}^{+} \\
\mathrm{Fe}^{3+}+2 \mathrm{H}_{2} \mathrm{O} \leftrightarrow \mathrm{Fe}(\mathrm{OH})_{2}^{+}+2 \mathrm{H}^{+} \\
\mathrm{Fe}^{3+}+3 \mathrm{H}_{2} \mathrm{O} \leftrightarrow \mathrm{Fe}(\mathrm{OH})_{3}+3 \mathrm{H}^{+?}
\end{gathered}
$$

Initial $\mathrm{pH}$ for all pulp density was adjusted at 2 . As can be seen in Fig. 1 with increasing the pulp density, highest value of $\mathrm{pH}$ rise to, 3.5>3.4>3.01>2.86, respectively related to $2.5,2,1.5$ and $1 \mathrm{wt} / \mathrm{vol} \%$ of pulp densities Which shows the activity of bacteria reduced.

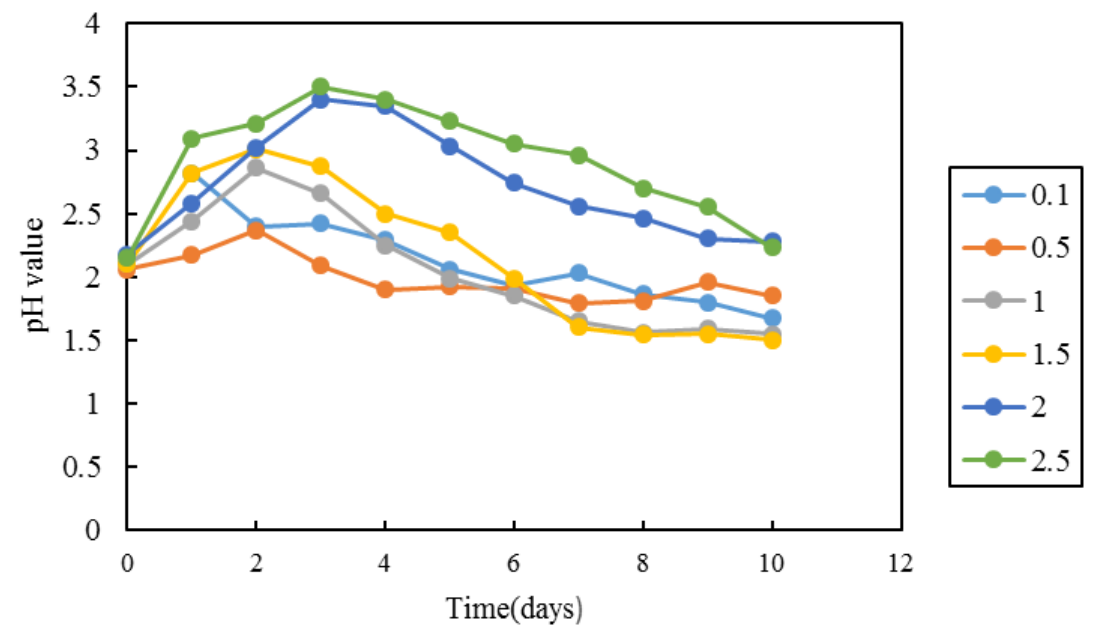

Fig. 1. The changes of $\mathrm{pH}$ value over time during adaptation process with variety of pulp densities $(\% \mathrm{w} / \mathrm{v})$.

\subsection{Oxidation-Reduction Potential and $\mathrm{Fe}^{3+}$}


In Fig. 2 shows the trend of ORP and $\mathrm{Fe}^{3+}$ during adaptation process. A rapid increase in the ORP and $\mathrm{Fe}^{3+}$ can be observed at the beginning of the process because of $A$. ferrooxidans used $\mathrm{Fe}^{2+}$ as energy source for growth and converted to $\mathrm{Fe}^{3+}$ as expressed by Eq. 1. Also, according to the nernst equation (Eq. 5) with increasing the $\mathrm{Fe}^{3+} / \mathrm{Fe}^{2+}$ ratio the Eh value rises. In the pulp densities 0.1-1.5 wt/vol.\% maximum ORP value was in the range of $500 \mathrm{mV}$ and then reached stability which indicates the bacteria is in the stationary phase.

$$
E=E^{0}+0.06 \log \left(\frac{F e^{3+}}{F e^{2+}}\right)
$$

After the addition of higher pulp density 2and $2.5 \mathrm{wt} / \mathrm{vol} . \%$, the highest ORP values decreased and stability at $400 \mathrm{mv}$. Also the trend obtained for $\mathrm{Fe}^{3+}$ is shown in Fig. 3. The total $\mathrm{Fe}^{3+}$ concentrations are increased for all pulp density due to bacterial activity. The maximum concentration of $\mathrm{Fe}^{3+}$ was $7000 \mathrm{ppm}$ at lowest pulp density ( $0.1 \mathrm{wt} / \mathrm{vol} . \%$,) with increasing pulp density until $2.5 \mathrm{wt} / \mathrm{vol} . \%$, the $\mathrm{Fe}^{3+}$ concentration decreased down to $100 \mathrm{ppm}$. In high pulp density the bacterial activity decreased due to decreasing in oxygen and carbon dioxide transmission rate, mechanical injury to the bacterial cells result in erosion between the particles of waste and the cells and the toxic effects of heavy metal ions in bacterial cells.

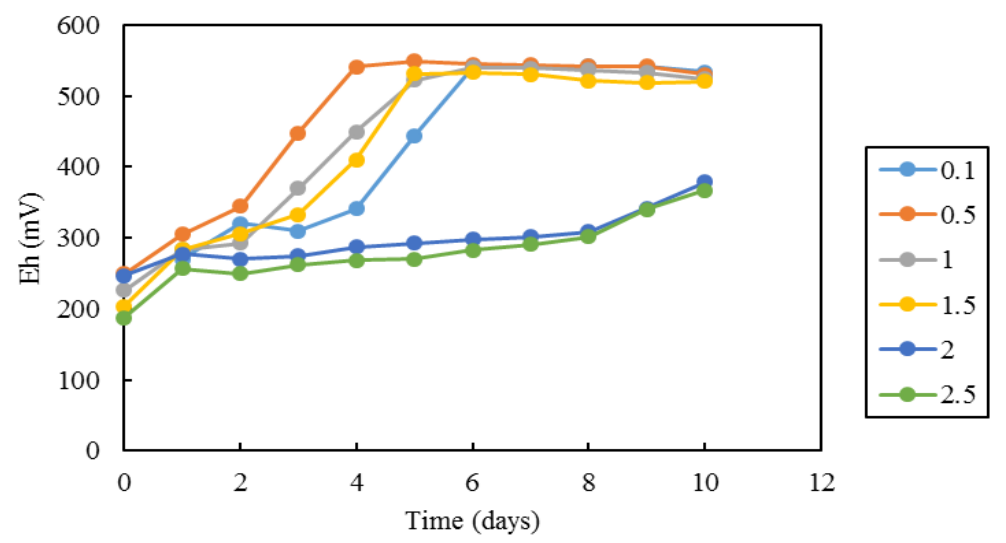

Fig. 2. ORP variation over time during adaptation process with variety of pulp densities $(\% \mathrm{w} / \mathrm{v})$.

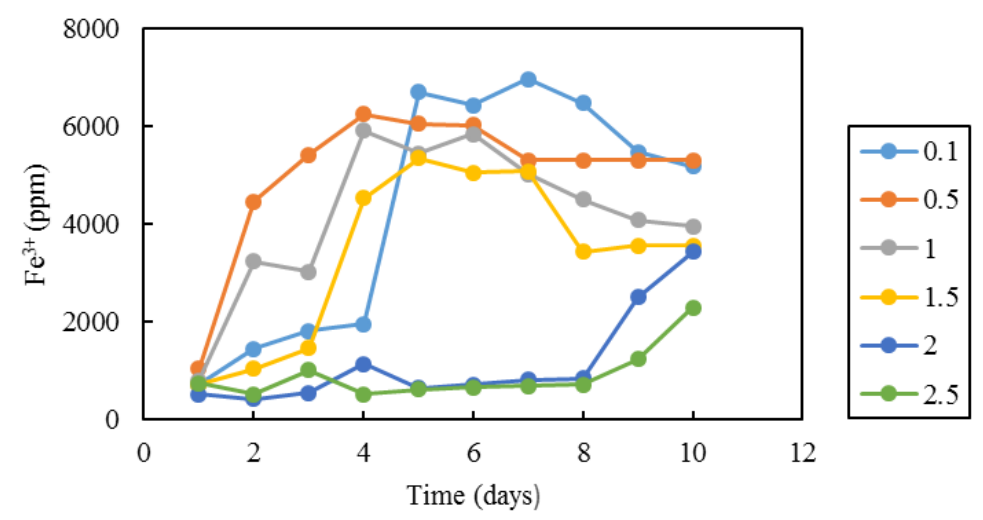

Fig. 3. The changes of concentration of ferric iron (Fe3+) production by A. ferrooxidans over time during adaptation process with variety of pulp densities $(\% \mathrm{w} / \mathrm{v})$.

\subsection{Cell Concentration}


The growth of $A$. ferrooxidans is characterized in Fig. 4. The different phases (i) the lag phase, (ii) the growth phase, (iii) stationary phase and death phase can be seen for pulp densities in range 0.1-1.5 wt $/ \mathrm{vol}$. \%. The effect of pulp density on length of lag phase can be observed when bacteria exposed to 0.1 $\mathrm{wt} / \mathrm{vol} \%$ pulp density shock came to bacteria so the lag phase is 8 days, in the pulp density $0.5 \mathrm{wt} / \mathrm{vol} . \%$ lag phase was reduced to 3 days then by increasing pulp density to $1.5 \mathrm{wt} / \mathrm{vol}$ lag phase increased. finally maximum time for lag phase in the pulp density 2, $2.5 \mathrm{wt} / \mathrm{vol} . \%$ is 10 days.

As can be seen in Fig. 4 the maximum cell concentration of bacteria was reduced from $10^{8}$ cells $/ \mathrm{mL}$ for $0.5 \mathrm{wt} / \mathrm{vol} . \%$ to $1.3 \times 10^{7}$ cells $/ \mathrm{mL}$ for $2.5 \mathrm{wt} / \mathrm{vol} . \%$ in the period of 10 days, because of metal ions created complex with protein molecules in bacteria and will be decreased its performance through inactivation of enzymes [16].

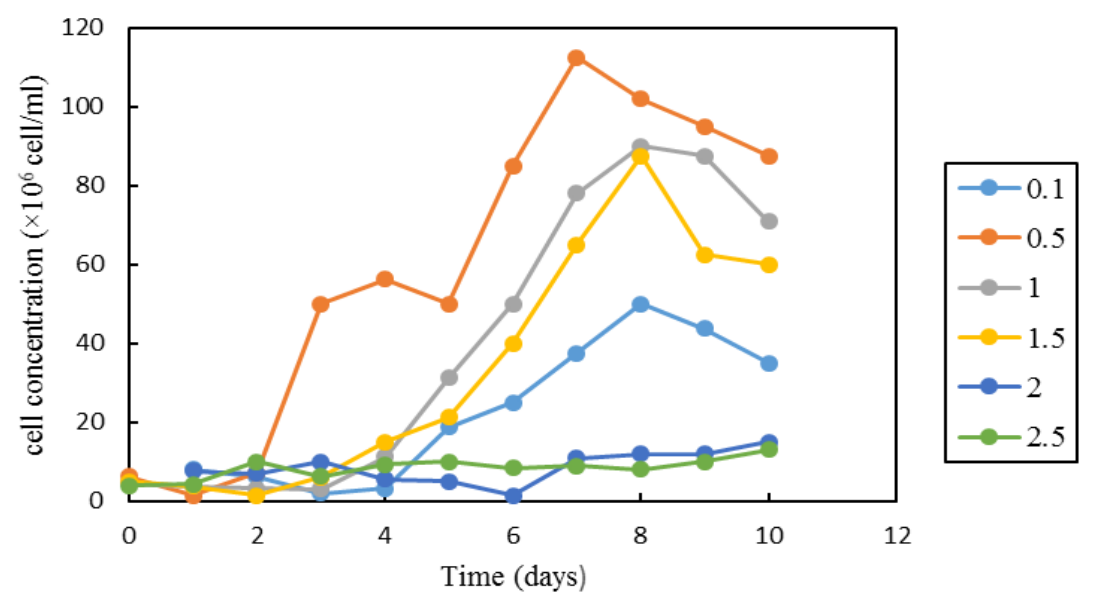

Fig. 4. The changes of bacterial cell concentration of $A$. ferrooxidans over time during adaptation process with variety of pulp densities $(\% \mathrm{w} / \mathrm{v})$.

\subsection{SEM}

In Fig. 5 shows surface morphology of the mobile phone touch screen sample by scanning electron microscope (SEM) before and after bioleaching. In Fig. 5(a) shows a clear surface of powder without coarseness before bioleaching process, the effect of bioleaching and bacterial activity on powder particle represents in Fig. 5(b).the image indicated clog formation and a significant scattering on powder particle.
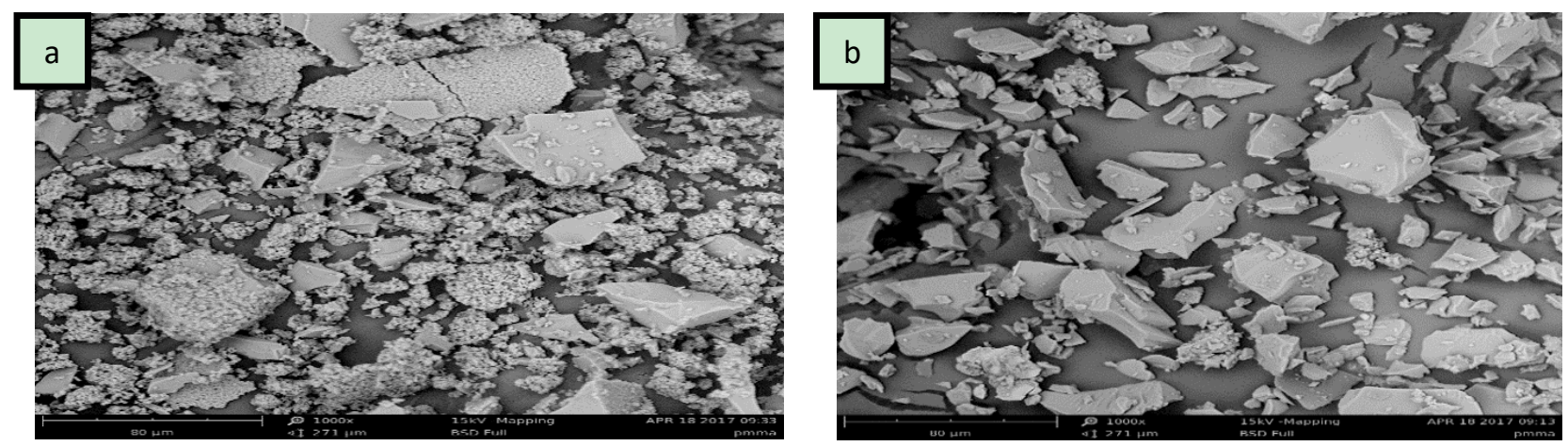

Fig. 5. SEM image of particle of mobile phone touch screen (a) before bioleaching and (b) residues bio-leached by Acidithiobacillus ferrooxidans in $9 \mathrm{~K}$ medium after 10 days; $\mathrm{T}=30^{\circ} \mathrm{C}, \mathrm{rpm}=140$, pulp density

$$
=1.5 \mathrm{wt} / \mathrm{vol} . \% \text {. }
$$

\subsection{Recovery}


In Fig. 6. the total Indium efficiency is shown for (a)adapted pure culture of A.ferrooxidans (b) non-adapted pure culture of A.ferrooxidans (c) control which performed in the presence of medium and $15 \mathrm{~g} / \mathrm{l}$ of sample without bacterial inoculation. The maximum indium recovery was observed with the adapted culture at 100\%. These indium removal efficiencies were obtained during 10 day of bioleaching process. Therefore, by comparing the results obtained for the indium recovery between the adapted culture and the non-adapted culture it can be concluded adaptation is needed to reach higher indium recovery and the bioleaching process has been completed successfully. The nan-adapted(b) bacteria could not resist the toxicity of powder therefore its growth stopped and the Indium recovery decrease down to $10 \%$.

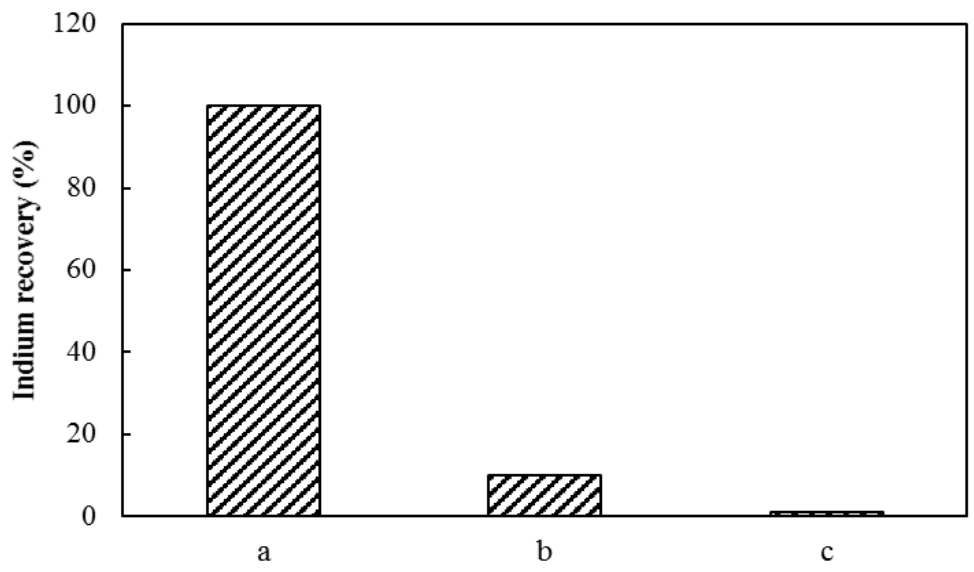

Fig. 6. Indium recovery after 10 days (a) adapted pure culture of A.ferrooxidans (b) non-adapted pure culture of A.ferrooxidans (c) control of A.ferrooxidans.

\section{Conclusion}

Adaptation of bacteria in the presence of mobile phone touch screen powder was successful. There are some reasons that can justify this phenomenon. The first reason is that there is a logical relationship between the trends of effective parameters such as $\mathrm{pH}, \mathrm{Eh}, \mathrm{Fe}^{3+}$ and cell concentration. The second reason refers to the performance of adapted and non-adapted bacteria which indicates that indium recovery percentage of adapted bacteria is $100 \%$ while no significant recovery was achieved by non-adapted bacteria. The whole adaptation process was done when having a wide range of pulp density from $0.1-2.5 \mathrm{wt} / \mathrm{vol} . \%$. When bacteria encounter a considerable amount of heavy metals, they will die because of the toxicity created in the media. Therefore, in order to solve this problem, it is essential that the bacteria become adapted with the heavy metals and consequently an acceptable bioleaching process will be achieved.

\section{References}

[1] Amankwah-Amoah, J. (2016). Global business and emerging economies: Towards a new perspective on the effects of e-waste. Technological Forecasting and Social Change, 105, 20-26.

[2] Soo, V. K., \& Doolan, M. (2014). Recycling mobile phone impact on life cycle assessment. Procedia CIRP, $15,263-271$

[3] Sarath, P., Bonda, S., Mohanty, S., \& Nayak, S. K. (2015). Mobile phone waste management and recycling: Views and trends. Waste Management, 46, 536-545.

[4] Savvilotidou, V., Hahladakis, J. N., \& Gidarakos, E. (2015). Leaching capacity of metals-metalloids and recovery of valuable materials from waste LCDs. Waste Management, 45, 314-324.

[5] Dodson, J. R., Hunt, A. J., Parker, H. L., Yang, Y., \& Clark, J. H. (2012). Elemental sustainability: Towards the total recovery of scarce metals. Chemical Engineering and Processing: Process Intensification, 51, 
69-78.

[6] Natarajan, G., \& Ting, Y. P. (2015). Gold biorecovery from e-waste: An improved strategy through spent medium leaching with $\mathrm{pH}$ modification. Chemosphere, 136, 232-238.

[7] Mrazikova, A., Marcincakova, R., Kadukova, J., \& Velgosova, O. (2014). Nickel recovery from printed circuit boards using acidophilic bacteria. Inżynieria Mineralna, 15.

[8] Jadhao, P., Chauhan, G., Pant, K. K., \& Nigam, K. D. P. (2016). Greener approach for the extraction of copper metal from electronic waste. Waste Management, 57, 102-112.

[9] Haghshenas, D. F., Alamdari, E. K., Torkmahalleh, M. A., Bonakdarpour, B., \& Nasernejad, B. (2009). Adaptation of Acidithiobacillus ferrooxidans to high grade sphalerite concentrate. Minerals Engineering, 22(15), 1299-1306.

[10] Molaei, S., Yaghmaei, S., \& Ghobadi, Z. (2011). A study of Acidithiobacillus ferrooxidans DSMZ 583 adaptation to heavy metals. Iranian Journal of Biotechnology, 9(2).

[11] Xia, L., Liu, X., Zeng, J., Yin, C., Gao, J., Liu, J., \& Qiu, G. (2008). Mechanism of enhanced bioleaching efficiency of Acidithiobacillus ferrooxidans after adaptation with chalcopyrite. Hydrometallurgy, 92(3), 95-101.

[12] Astudillo, C., \& Acevedo, F. (2008). Adaptation of Sulfolobus metallicus to high pulp densities in the biooxidation of a flotation gold concentrate. Hydrometallurgy, 92(1), 11-15.

[13] Karamanev, D. G., Nikolov, L. N., \& Mamatarkova, V. (2002). Rapid simultaneous quantitative determination of ferric and ferrous ions in drainage waters and similar solutions. Minerals Engineering, 15(5), 341-346.

[14] Vakilchap, F., Mousavi, S. M., \& Shojaosadati, S. A. (2016). Role of Aspergillus niger in recovery enhancement of valuable metals from produced red mud in Bayer process. Bioresource Technology, 218, 991-998.

[15] Bajestani, M. I., Mousavi, S. M., \& Shojaosadati, S. A. (2014). Bioleaching of heavy metals from spent household batteries using Acidithiobacillus ferrooxidans: statistical evaluation and optimization. Separation and Purification Technology, 132, 309-316.

[16] Ilyas, S., Ruan, C., Bhatti, H. N., Ghauri, M. A., \& Anwar, M. A. (2010). Column bioleaching of metals from electronic scrap. Hydrometallurgy, 101(3), 135-140.

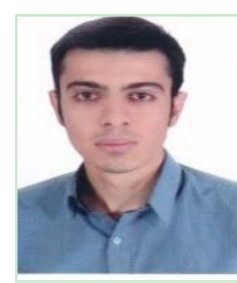

Omid Rezaei was born in Isfahan, Iran. He obtained his bachelor degree of chemical engineering from University of Kashan, Iran. Currently, he is pursuing his master at Tarbiat Modares University, Iran in chemical engineering- biotechnology.

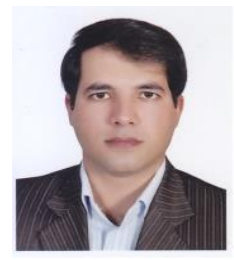

Seyyed Mohammad Mousavi was born in 1978 in Iran. He received his $\mathrm{PhD}$ degree in chemical engineering from Sharif University of Technology in 2007, Iran. At the moment, he is an associate professor of industrial biotechnology in department of chemical engineering at Tarbiat Modares University. He is author of more than 120 ISI papers and 40 national and international conferences. Dr. Mousavi interested in environmental biotechnology especially in bioleaching of hazard wastes, mathematical modeling and simulation of biological phenomena, statistical modelling and optimization of biochemical processes and computational fluid dynamics. 
Fatemeh Pourhossein is currently a $\mathrm{PhD}$ student at Tarbiat Modares University, Department of Chemical Engineering. She is researching on the topic of electronic waste management. Her main fields of interest are ecotoxicology, waste management, environmental impact assessment, risk analysis and remediation of contaminated sites. She is received the MSc degree in chemical engineering from Babol (Noshirvani) University of Technology with a thesis on "synthesis thin film nano composite membrane for water desalination". 